\title{
BMJ Global Health The promise and perils of Unit 731 data to advance COVID-19 research
}

To cite: Su Z, McDonnell D, Cheshmehzangi $\mathrm{A}$, et al. The promise and perils of Unit 731 data to advance COVID-19 research. BMJ Global Health 2021;6:e004772. doi:10.1136/ bmjgh-2020-004772

Handling editor Seye Abimbola

Received 16 December 2020 Revised 17 April 2021

Accepted 17 April 2021

Check for updates

(c) Author(s) (or their employer(s)) 2021. Re-use permitted under CC BY-NC. No commercial re-use. See rights and permissions. Published by BMJ.

For numbered affiliations see end of article.

\section{Correspondence to}

Dr Zhaohui Su;

szh@utexas.edu and

Dr Yuyang Cai;

caiyuyang@sjtu.edu.cn

\author{
Zhaohui Su (D) ," Dean McDonnell (1) ,2 Ali Cheshmehzangi (i) , Jaffar Abbas (D) , \\ Xiaoshan Li (1) , ${ }^{5}$ Yuyang Cai (1) ${ }^{6,7}$
}

\section{INTRODUCTION}

Emerging evidence shows that the COVID-19 is mutating ${ }^{1}$; as of April 2021, COVID-19 mutations are identified in most of the countries worldwide. ${ }^{2}$ The scale and scope of these mutations could have a devastating effect on global pandemic control and vaccine development efforts. ${ }^{3}{ }^{4}$ Furthering this perspective, the first mutation identified in the UK, the B.1.1.7 variant, is up to $70 \%$ more transmissible and $35 \%$ more deadly than the original coronavirus. ${ }^{56}$ As COVID-19 evolves its approaches to spread across communities of various backgrounds, we must also adapt and update our defensive methods promptly and adequately. In other words, to gain an in-depth and comprehensive understanding of COVID-19, such as its transmissibility and human-pathogen interaction, critical scientific evidence is needed. Comparing data from previous pandemics, such as the severe acute respiratory syndrome and the Middle East respiratory syndrome, fundamental differences in terms of transmission and mutation patterns supported the initial scientific push back against COVID-19. ${ }^{7-9}$ However, latent information from the past can lead to better insights into the future. A closer examination of available evidence indicates that one historical event may hold the key to better control and management of infectious diseases like COVID-19: Unit $731 .{ }^{10-13}$

\section{UNIT 731: A DARK AND EVIL EXISTENCE}

Less discussed than the Holocaust forced on Jewish people during World War II, Unit 731 is Japan's covert biological and chemical research division that primarily operated in China between 1932 and $1945 .^{10-14}$ Unit 731 performed medical experiments, such as human vivisections, on detained Chinese, Koreans, Mongolians, Russians and Americans, including the young, the old and the

\section{Summary box}

COVID-19 is mutating; unknowns about virulent COVID-19 variants can result in devastating effects on pandemic control and management.

- Scientific evidence on human-pathogen interactions, such as data from Unit 731, can help epidemiologists better understand pandemics of COVID-19's scale.

- Unit 731 is unique in its litany of malicious humanmade plagues unleashed on predominantly Chinese people in their natural environments, unprecedented medical atrocities done to gauge how various deadly pathogens affect the human body at complex and comprehensive levels.

- Although viewed as barbaric, these experiments left data that may help the international medical community better understand and control the COVID-19 pandemic; however, neither the Japanese government nor the US government, both of which have access to Unit 731 data, has made Unit 731 data available to the international medical community.

- This paper examines the scientific advances society can gain from applying Unit 731 data to research COVID-19 and future pandemics; furthermore, we discuss the imperative of addressing moral and ethical considerations associated with the application of Unit 731 data even in light of global health crises like COVID-19.

pregnant. ${ }^{10-15}$ Human vivisections are medical experiments conducted on live and conscious human beings. During these experiments under Unit 731, captured individuals were rarely given anaesthetics and often suffered through amputations, burning, or forced consumption of toxins or poisons while awake; many observations were recorded during these procedures. ${ }^{10-15}$

At the centre of these medical atrocities are Unit 731's biological warfare experiments, epitomised by the litany of maliciously human-made plagues unleashed on noncaptured Chinese civilians in their homes and communities. These experiments aimed to determine human-pathogen interactions 
at various levels, such as how viruses interact with their human hosts and how these viruses and infections evolve during the process. ${ }^{10-15}$ Diseases, pathogens and plagues were of particular interest to Unit 731 medical practitioners. ${ }^{3}$ Emerging evidence suggests that Unit 731 may have deliberately engineered and disseminated at least four deadly infectious pathogens, namely anthrax, plague, cholera and glanders. ${ }^{10-15}$ In each of these known atrocities, it is possible that Unit 731 possesses one of the most exhaustive medical datasets on human-pathogen interactions across these deadly and engineered plagues. ${ }^{13}$ These insights are of particular importance, as highlighted by the COVID-19 pandemic, our current understanding of infectious diseases is too limited to shed light on issues such as virus mutations and evolution promptly. ${ }^{3}$ Making the data even more applicable is that it explores how viruses interact with humans in their natural environment and how this process progresses over time. ${ }^{15}$

\section{UNIT 731 DATA: POTENTIAL GLIMMER OF HOPE TO ADVANCE COVID-19 RESEARCH}

Debate within the medical community on how Unit 731 data might benefit societies at large, including Japanese individuals, in the wake of pandemics of COVID19 's scale, should be initiated and invigorated promptly and based on rigorous research. It is important to note that it is in the Japanese government's interest to share Unit 731 medical data, including information on how Unit 731 data may have shaped Japan's medical capabilities. As seen in infectious diseases across space and time, ranging from the 1918 influenza outbreak to the COVID-19 pandemic, communicable illnesses impact all societies, including people living in Japan. Sharing Unit 731 data with the medical community would allow both the Japanese government and the rest of the world to analyse the data with more advanced medical technologies. In light of the destruction caused by COVID-19, including its more transmissible and deadly mutations (eg, the B.1.351 and B.1.1.7 variants), ${ }^{16} 17$ and the fact that many parts of the world are without mass immunisation of COVID-19 vaccines until 2024, ${ }^{18}$ any advancements related to insights obtained from Unit 731 experiments are needed now more than ever. Although there is some evidence that the USA possesses some of the Unit 731 data, obtained through clandestine negotiations at the end of the Pacific War, ${ }^{190}$ sharing Unit 731 data with the medical community could curb the tide of further waves of COVID-19.

At the time, the US government wanted data about biological weapons for its research and purposes. Thus, they agreed not to prosecute the Unit 731 perpetrators in exchange for at least some of the data. ${ }^{190}$ In other words, even scientists back then understood the importance of Unit 731 data in enriching our understanding of infectious diseases and beyond, a time when the world was not struggling to fight COVID-19-an extremely contagious and deadly global pandemic. As of 17 April 2021, COVID-19 has at least claimed 139 million infections and 3 million deaths, a situation that may further deteriorate by new COVID-19 mutations ranging from the 'Cluster 5' (first identified in Denmark), the B.1.351 variant (first identified in South Africa), to the B.1.1.7 variant (first identified in Britain). ${ }^{2}$ Overall, to help societies at large effectively stall or stem the spread of COVID-19, both the Japanese and the US government should help the international medical community better understand the nature of the records and data they withheld the rest of the world about Unit 731.

\section{UNIT 731 DATA: MORAL AND ETHICAL CONSIDERATIONS}

Some debates relating to the utilisation of Unit 731 data are rooted in moral and ethical considerations. These debates can be categorised into three schools of thought: (1) using the data is not permissible, for the reason that the tortured and killed victims would be wronged anew by the use of this data; (2) using the data is not permissible, for the consideration that at least some insights could be gained from Unit 731 experiments; and (3) using the data is not permissible under certain circumstances, for instance, the Unit 731 data will only be used with all ethical standards sufficiently met, and under the condition that there are no alternative ethical ways to obtain similar data to avert exceptionally high amounts of suffering, a situation similar to what the world is experiencing now with COVID-19.

It is important to note that the victims who suffered at the hands of Unit 731 perpetrators should not be ignored or dismissed. However, while condemnation is warranted regarding the brutal and barbaric ways in which Unit 731 obtained its data on human-plague interactions, ${ }^{10-12} 15$ considering the ongoing devastating suffering people endure amid COVID-19 across the world, it is perhaps more than urgent and necessary for the medical community to use Unit 731 data and find ways to halt the pandemic effectively and promptly. By 'medical community', we mean a carefully selected group of scientists and scholars who have adequate knowledge and experience regarding the best approaches to analyse medical data of Unit 731's scale, as well as sufficient ethical training on what is required to protect the data correctly. Due to the global medical community's limited understanding of Unit 731 data, much is still unknown about these data's scale and scope.$^{13}$ Therefore, it is of utmost importance that access to Unit 731 data is granted to sufficiently vouched and validated medical scientists, so that much-needed discussions about (1) how to protect Unit 731 data from bad actors with malicious intentions, (2) whether to leverage Unit 731 for better fending off COVID-19 and future pandemics, and (3) what procedures should be taken to adequately address the pain and sufferings of Unit 731 victims, regardless of whether its data are suitable to be used and studied for scientific purposes. 
It is also important to acknowledge that there is a possibility that Unit 731 data may not be relevant to COVID$19,{ }^{13}$ or the relevance of the data may not be high enough to COVID-19 to make a difference to the current research and understanding of the pandemic. However, it is equally important to note that the lack of understanding of Unit 731 data could be one key reason why the medical community needs to access these data. According to the WHO, the next pandemics we face could be substantially more deadly and destructive than COVID-19, ${ }^{21}$ which means that we would need to use all resources available to make sure societies at large are well prepared for future challenges. ${ }^{22}$ It is of utmost importance that when we face future pandemics, we have all the relevant knowledge needed to fight these global health crises. Even if Unit 731 data are of little use to these pandemics, providing health experts with this information may support the effort and allow us to respond aggressively to COVID-19 rather than continuing to be reflexive.

\section{CONCLUSION}

Overall, the question of whether to apply insights obtained from unethical areas of science is controversial. ${ }^{13}$ The potential for healthy debate around the use of Unit 731 data to curb the spread of COVID-19 can only become meaningful once at least some highly qualified medical scientists are granted access to Unit 731 data, and understand the potential benefits and challenges of using such data. In light of the COVID-19 pandemic, along with the lives, livelihoods and economics upended by the pandemic, applying insights from Unit 731 to inform COVID-19 research should at least be thoroughly considered. Two lessons the pandemic taught humanity are that: (1) infectious diseases like COVID-19 do not discriminate, people are susceptible to the virus and its variants, regardless of their nationality, religion, race or ethnicity; and (2) scientific evidence and data hold the key to curb the COVID-19 pandemic.

The horrors experienced by individuals at the hands of Unit 731 are as unfathomable as they are undeniable. ${ }^{10-15}$ However, it is unquestionable that the potential for Unit 731 data to advance research on COVID-19 and future pandemics alone justifies an international inquiry into the scale and scope of Unit 731 data. Considering the possibility that Unit 731 data could untangle critical unknowns associated with global health crises, such as how human interactions with deadly pathogens might shape these pandemics' evolution trajectory, the Japanese and the US government should be transparent with the international medical community about Unit 731 data. It is important to note that, without timely access to Unit 731 data, robust and rigorous research cannot be carried out to investigate the promise and perils of Unit 731 data, such as whether they hold the key to control and manage COVID-19 and future pandemics effectively.

\section{Author affiliations}

${ }^{1}$ Center on Smart and Connected Health Technologies, Mays Cancer Center, School of Nursing, UT Health San Antonio, San Antonio, Texas, USA

${ }^{2}$ Department of Humanities, Institute of Technology Carlow, Carlow, Ireland ${ }^{3}$ Architecture and Built Environment, University of Nottingham, Ningbo, Zhejiang, China

${ }^{4}$ Antai College of Economics and Management, and School of Media and Communication, Shanghai Jiao Tong University, Shanghai, China

${ }^{5}$ Program of Public Relations and Advertising, Beijing Normal University-Hong Kong Baptist University United International College, Zhuhai, Guangdong, China

${ }^{6}$ School of Public Health, Shanghai Jiao Tong University School of Medicine, Shanghai, China

${ }^{7}$ China Institute for Urban Governance, Shanghai Jiao Tong University, Shanghai, China

Acknowledgements The authors wish to express their deepest gratitude to the editor and the reviewers for their constructive input and valuable insights. In addition, the authors also wish to say thanks to Dr. Jing-Bao Nie for his kind feedback.

Contributors ZS conceived the work, reviewed the literature, drafted and edited the manuscript. DM, AC, JA and YC reviewed the literature and edited the manuscript. All authors approved the manuscript for submission.

Funding This work was supported by the National Natural Science Foundation of China (71432006); the National Social Science Fund of China (17BSH056); and the Shanghai Jiao Tong University think tank research project (ZKYJ-20200114).

Disclaimer The views, thoughts, and opinions expressed in this study belong solely to the authors, and not necessarily to the authors' employers, organizations, committees, or other groups or individuals.

Competing interests None declared.

Patient consent for publication Not required.

Provenance and peer review Not commissioned; externally peer reviewed.

Data availability statement Data are available upon reasonable request.

Open access This is an open access article distributed in accordance with the Creative Commons Attribution Non Commercial (CC BY-NC 4.0) license, which permits others to distribute, remix, adapt, build upon this work non-commercially, and license their derivative works on different terms, provided the original work is properly cited, appropriate credit is given, any changes made indicated, and the use is non-commercial. See: http://creativecommons.org/licenses/by-nc/4.0/.

\section{ORCID iDs}

Zhaohui Su http://orcid.org/0000-0003-2005-9504

Dean McDonnell http://orcid.org/0000-0001-6043-8272

Ali Cheshmehzangi http://orcid.org/0000-0003-2657-4865

Jaffar Abbas http://orcid.org/0000-0002-8830-1435

Xiaoshan Li http://orcid.org/0000-0002-1765-4815

Yuyang Cai http://orcid.org/0000-0003-1500-8518

\section{REFERENCES}

1 Grubaugh ND, Hanage WP, Rasmussen AL. Making sense of mutation: what D614G means for the COVID-19 pandemic remains unclear. Cell 2020;182:794-5.

2 World Health Organization. SARS-CoV-2 variants, 2020. Available: https://www.who.int/csr/don/31-december-2020-sars-cov2-variants/ en/ [Accessed 7 Jan 2021].

3 Kupferschmidt K. Viral mutations may cause another 'very, very bad' COVID-19 wave, scientists warn, 2021. Available: https://www. sciencemag.org/news/2021/01/viral-mutations-may-cause-anothervery-very-bad-covid-19-wave-scientists-warn [Accessed 7 Jan 2021].

4 Su Z, McDonnell D, Cheshmehzangi A, et al. With great hopes come great expectations: a viewpoint on access and adoption issues associated with covid-19 vaccines. JMIR Public Health Surveill 2021. doi:10.2196/26111. [Epub ahead of print: 01 Feb 2021].

5 Wise J. Covid-19: new coronavirus variant is identified in UK. BMJ 2020;371:m4857. 
6 Mallapaty S. What's the risk of dying from a fast-spreading COVID-19 variant? 2021 (accessed February 6 2021).

7 Cevik M, Kuppalli K, Kindrachuk J, et al. Virology, transmission, and pathogenesis of SARS-CoV-2. BMJ 2020;371:m3862.

8 Davey Smith G, Blastland M, Munafò M. Covid-19's known unknowns. BMJ 2020;371:m3979.

9 Petrosillo N, Viceconte G, Ergonul O, et al. COVID-19, SARS and MERS: are they closely related? Clin Microbiol Infect 2020;26:729-34.

$10 \mathrm{~K}-\mathrm{i}$ T. Unit 731 and the human skulls discovered in 1989: physicians carrying out organized crimes. Dark medicine: Rationalizing unethical medical research 2007:73-84.

11 Brody H, Leonard SE, Nie J-B, et al. U.S. responses to Japanese wartime inhuman experimentation after World War II. Camb Q Healthc Ethics 2014;23:220-30.

12 Nie JB. Japanese doctors' experimentation in wartime China. Lancet 2002;360 Suppl:s5-6.

13 Bärnighausen T. Data generated in Japan's biowarefare experiments on human experiments on human victims in China, 1932-1945, and the ethics of using them. In: Nie JB, Guo N, Selden M, et al, eds. Japan's wartime medical atrocities: Comparative inquiries in science, history, and ethics. London: United Kingdom: Routledge, 2010: 80-106.

14 Tsuneishi K. Unit 731 and the Japanese Imperial Army's biological warfare program. The Asia-Pacific Journal 2005;3:1-9.
$15 \mathrm{Nie}$ JB, Guo N, Selden M, et al. Japan's wartime medical atrocities: Comparative inquiries in science, history, and ethics. London: United Kingdom: Routledge, 2010.

16 Johns Hopkins University. The COVID-19 global MAP, 2021. Available: https://coronavirus.jhu.edu/map.html [Accessed 8 Apr 2021].

17 Johns Hopkins University. The COVID-19 global MAP, 2020 Available: https://coronavirus.jhu.edu/map.html [Accessed 6 Jan 2021].

18 Duke Global Health Innovation Center. Interactive COVAX MAP, 2020. Available: https://launchandscalefaster.org/COVID-19 [Accessed 6 Jan 2021].

19 Nie J-B, Tsuchiya T, Li L. Japanese doctors' experimentation, 19321945, and medical ethics. In: McCullough LB, Baker RB, eds. The Cambridge world history of medical ethics. Cambridge: Cambridge University Press, 2008: 589-94.

20 Harris SH. Factories of death: Japanese biological warfare, 1932-45 and the American cover-up. New York: Routledge, 2002.

21 World Health Organization. The best time to prevent the next pandemic is now: countries join voices for better emergency preparedness, 2020. Available: https://www.who.int/news/item/ 01-10-2020-the-best-time-to-prevent-the-next-pandemic-isnow-countries-join-voices-for-better-emergency-preparedness [Accessed 11 Dec 2020]

22 Su Z, McDonnell D, Ahmad J. The need for a disaster readiness mindset: a key lesson from COVID-19. Infection Control \& Hospital Epidemiology 2021. 